\title{
VENEREAL DISEASE IN LITERATURE*
}

\author{
By J. D. ROLLESTON, M.D., F.R.C.P., F.S.A.
}

IN no department of medicine is a knowledge of the lay writers on the history of the subject more necessary than in the domain of venereal disease. As will be seen in the course of this paper, the information both of a positive and of a negative character furnished by contemporary writers, such as poets, dramatists, novelists and historians, is a valuable supplement to that derived from the study of the medical works of the time. Systematic investigation of the references to venereal disease in non-medical literature, side by side with study of the works of medical historians, has been undertaken by numerous writers, of whom the best known are Astruc, Hensler, Girtanner, Rosenbaum, Dufour, Buret, Proksch, Creighton, Iwan Bloch and Jeanselme.

My task, if one may apply so dreary a term to what has been in every sense a labour of love, has been greatly facilitated by my researches on the medical aspects of certain Greek and Latin classical writers (I9I3, I9I5), the works of Voltaire (I925) and Casanova (I9I7), and a study of Chaucer and mediæval medicine (I933). In the present paper, which in the short time at my disposal is necessarily very incomplete, I shall deal with some of the allusions to the three principal venereal diseases in nonmedical literature from the earliest times down to the present day.

\section{SYPHILIS}

The references to this disease will be considered under the seven headings of (I) the Bible, (2) Classical Antiquity, (3) the Middle Ages, (4) the Sixteenth Century, (5) the Elizabethan Age, (6) the Eighteenth Century, (7) Modern Times.

The Bible.-Some writers, notably Rosenbaum, Proksch and Buret, are inclined to regard certain passages in the Bible as references to syphilis, such as the descriptions

* A Paper read before the Medical Society for the Study of Venereal Diseases on May 3oth, r934. 


\section{BRITISH JOURNAL OF VENEREAL DISEASES}

of the plague of Egypt (Exod. ix. Io-II), the plague of Baal-Peor (Num. xxv. 3), and the disease which attacked the Philistines (I Sam. v. and vi.). According to these authorities also, certain Old Testament personages were victims of syphilis, viz., Pharaoh, who contracted it from Sarah (Gen. xii.), David, who was infected by Bathsheba (II. Sam. xi. 4), and Job, whose source of infection is not stated. The existence of syphilis in biblical times appeared all the more likely owing to the prevalence in that age of prostitution, which has always been the chief source of infection. I need only refer to the numerous passages in Strong's Concordance, in which the terms " harlot," " whore" and the like occur. It is noteworthy, however, that in his "Medical Sacra, or Commentary on the Most Remarkable Diseases mentioned in the Holy Scriptures" (I749), the scholarly Richard Mead makes no mention of syphilis, or indeed of any venereal disease whatever, as occuring in biblical characters. Moreover, the principal authorities of modern times, including Wilhelm Ebstein, Iwan Bloch, Preuss and Jeanselme, agree with Astruc that there is no definite evidence that the biblical passages mentioned have anything to do with syphilis.

According to Preuss, the pestilence of Baal-Peor and the disease of the Philistines were plague and not syphilis, while Job's disease represented merely the moral and material sufferings inflicted by God on man to test his true worth.

Classical Antiquity.-The existence of syphilis in ancient Greece and Rome was denied by the eighteenthcentury historians such as Astruc, Le Clerc, Freind, van Swieten, Girtanner and Hensler, but maintained by subsequent authorities such as Rosenbaum, Dufour, Buret, Proksch, Hirsch and Creighton, and again denied by Iwan Bloch, Jeanselme and Pusey, according to their different interpretation of certain passages in non-medical as well as in professional literature. In the vast collection of epigrams extending over many centuries known as the Greek Anthology, as I pointed out in I9I3 there is nothing whatever suggestive of syphilis. This is all the more remarkable as two sections, the fifth and the twelfth, dealing with normal and homosexual relations respectively, consist entirely of erotic poems, and many of the epigrams are conspicuous for their frank presentation of 


\section{VENEREAL DISEASE IN LITERATURE}

the physical side of sexual life. Moreover, if syphilis had been known to the ancients, there would undoubtedly have been reference to its phenomena in the eleventh or comic section, whereas nothing of the kind can be found, the only pathological sexual manifestation mentioned being impotence of a temporary or senile character which is treated in the same satirical spirit as in Ovid or Martial. Some epigrams on Priapus (Anth. Plan., 237, 24I, 243) are of special interest in that this demigod threatens thieves with padicatio as a punishment. As Iwan Bloch remarks in dealing with the Carmina Priapeia, this would have been the occasion to have threatened syphilis as a punishment had it been in existence, but neither in the Greek nor in the Latin poems is there any such suggestion. Lucian's works also are remarkable for a similar frank presentation of normal and aberrant sexuality which forbids a literal translation into any modern language. Had syphilis been in existence in his time, Lucian would undoubtedly had presented one or more of his amorous gods or philosophers as victims of the disease, just as his modern counterpart, Voltaire, has done in the case of the optimist philosopher, Dr. Pangloss, in "Candide." But neither in the " Dialogues of Courtesans," the " Amores," the "Asinus," or the "Adversus Indoctum," to mention the most likely pieces, nor in any of the others, is there a passage which could be tortured by an ingenious commentator to have any reference to syphilis or indeed to any venereal disease.

As regards the Latin poets, several passages are to be found in Juvenal (II., I2) and Martial (VI., 49; VII., 7I; XI., I5) as well as in the Carmina Priapeia (37) relating to lesions of the penis and anus, but these are of an exclusively local character, and may be regarded mainly as examples of herpes progenitalis, chancroid or granuloma venereum, while there is nothing to indicate that general infection followed. The condition called "morbus campanus" by Horace (Sat., I., V.) and " mentagra " by Pliny (Hist. Nat., XXVI., I, 2) is much more likely to have been sycosis than any other disease, although Rosenbaum, Proksch and Buret appear to have no hesitation in regarding it as a syphilitic eruption.

As regards the historians of Ancient Rome, the description of the face of Tiberius by Suetonius, Tacitus and Julian as covered with small ulcers to which plasters had 


\section{BRITISH JOURNAL OF VENEREAL DISEASES}

been applied has suggested syphilis, but here again the evidence of this disease is quite inadequate. Some of the historians of the nineteenth century, such as Rosenbaum and Buret, showed too great a tendency to regard any ulceration or gangrenous lesion as syphilitic, especially when the external genitals were affected. Buret, for example (I89I, I46), considers that the pestilence of Athens as described by Thucydides was an outbreak of syphilis because destruction of the external genitals was a sequel, whereas the disease was most probably typhus, of which gangrene of the external genitals is a well-recognised complication. The Egyptian or Syriac ulcer described by Aretæus, which was undoubtedly laryngeal diphtheria, was also regarded by Buret (I89I, I37) as syphilis. The same historian interprets the destructive lesion of the face which carried off the young slave girl in Martial's touching epigram (XI., 9I) as a precocious tertiary lesion, whereas it was much more likely to have been cancrum oris.

The absence of any definite description of syphilis by the lay writers of classical antiquity is in striking contrast, as Astruc points out, with the outspoken comments on the new disease made by French poets after the introduction of syphilis into Europe at the end of the fifteenth century. "Every one knows," says Astruc (I., 4), "what coarse Raillery is to be found on this Subject in the Satyrs of Regnier, Marot, Bayf, Theophile, Sigogne, Berthelotte, St. Amand, Rouselle, etc. or in the Adventures of Gargantua and Pantagruel by Rabelais. . . . Shall we imagine that such obscene and abusive Writers as Horace, Juvenal and Persius were more restrained than Regnier the Satyrist or that Catullus or Martial who never spare for a loose Reflection were more modest than Marot, Bayf, Theophile, Sigogne, Berthelotte, St. Amand and Rouselle, or that Petronius, a Writer who has raked in all the Filth and Nastiness of Stews and Brothels was more shamefaced than Rabelais? This can never be imagin'd.'

Finally, I may quote Norman Moore's suggestion that had syphilis been in existence in Ancient Greece and Rome general paralysis would undoubtedly have occurred, but no descriptions of such a disease are to be found in any of the writers of classical antiquity.

Middle Ages.-In the paper on Chaucer and Mediæval 


\section{VENEREAL DISEASE IN LITERATURE}

Medicine which I read before the Ninth International Congress of the History of Medicine at Bucharest in September, I932, I pointed out that in view of the frank presentation of the physical side of sexual life in Chaucer's works the absence of any reference to syphilis which was so frequently mentioned in Shakespeare two centuries later was extremely valuable evidence against the existence of the disease in the Middle Ages. Had syphilis been prevalent then, Chaucer would most probably have represented one or more of the free living Canterbury pilgrims as suffering therefrom, and the section in the Parson's Tale relative to "leccherie" would have included a warning of the dangers awaiting the sinner in this world. There is a similar absence of any allusion to anything suggestive of syphilis or indeed of any venereal disease in the other two great English poets of the Middle Ages, viz., Langland, the author of "Piers Plowman," and Gower, the author of " Confessio Amantis." In both these poems appears a personification of the seven deadly sins including "leccherie," in the description of which there would have been an ample opportunity for a realistic presentation of syphilis had it been known to Langland or Gower. The similar lack of any reference to venereal disease in Boccaccio's "Decameron," which first appeared in 1353, and in the unexpurgated version of the "Arabian Nights," the date of which is about the middle of the fifteenth century, or about fifty years after Chaucer's death, may also be regarded as evidence against the existence of syphilis in Europe in the pre-Columbian era. As regards mediæval literature generally, Dr. G. G. Coulton, the well-known mediæval scholar, has kindly answered my inquiry on this subject as follows: "I have no hint whatever pointing to the existence of syphilis in the Middle Ages. I have always looked upon the fact that nobody has managed to mention anything of the kind as practically conclusive of the novelty of the disease at the Renaissance." I am also indebted to Dr. G. W. Owst, the author of " Preaching in Mediæval England " (I926) and " Literature and Pulpit in Mediæval England " (I933), for informing me that the vast quantity of mediæval sermon literature which deals in such an outspoken manner with the subject of sexual immorality contains no indication of the likelihood of venereal disease as a consequence. 


\section{BRITISH JOURNAL OF VENEREAL DISEASES}

According to Buret (I894, 89), Polycarpe Leyser's collection of mediæval poems contains some verses of the twelfth and thirteenth centuries alluding to sexual affections of venereal origin, but the specimens which he gives do not indicate definitely the venereal nature of the disease. Buret is also inclined to the view that Villon (c. I460) is referring to venereal disease in his "Grand Testament," but Le Pileur is probably more correct in interpreting the various skin lesions mentioned in this poem as scabies or eczema. It is important to realise, as Iwan Bloch and Le Pileur have pointed out, that the term "venereal disease" did not exist in the Middle Ages any more than it did in classical antiquity. The term "morbus venereus" was first introduced by Jacques de Bethencourt in 1527 , that of the "lues venerea " in 1548 by Jean Fernel, and that of " maladie vénérienne " in 1552 by Thiery de Héry. According to the Oxford Dictionary, the earliest use of the term "venereal" was not until 1658 , and that of the closely allied term "venerean" some forty years earlier (I6I7). Before taking leave of the Middle Ages I should add that Jeanselme has studied the vast collection of Byzantine historians which contains an abundance of pathological material, but has been unable to find a single passage referable to syphilis. $\mathrm{He}$ has come to the conclusion that all documents concerning syphilis with a date prior to I493 are apocryphal, either because they are antedated by fraud or error, or because interpolated passages have been introduced into the text.

Sixteenth Century.-In striking contrast with the absence of any certain reference to the existence of syphilis prior to the siege of Naples in I495, an immense amount of literature, lay as well as medical, dealing with various aspects of the new disease followed that event. Among the very earliest writers on syphilis were such eminent laymen as Sebastian Brandt (I458-1520), best known for his work entitled " Der Narrenschiff" (" The Ship of Fools "), who in 1496 wrote a poem consisting of I24 elegiac verses entitled " De pestilentiali Scorra sive mala de Franzos," relating how the disease had spread all over Europe and the doctors had no remedy for it. About the same time Joseph Grünpeck, a cleric and secretary to the emperor Maximilian I., published a prose work with a similar title, and in 1503 another book 


\section{VENEREAL DISEASE IN LITERATURE}

entitled "Libellus de mentulagta, alias morbo gallico" (Sudhoff and Singer, Jeanselme). Other early lay writers on the disease were Philippus Beroaldus, whose "Commentarius in Apuleii asinum amicum," published at the beginning of the sixteenth century, contains the statement that the disease was new, unknown to the ancients, and that the most characteristic symptom was pain in the bones. The earliest and most remarkable belletristic work on syphilis, however, appears to be that of the French poet, Jean Droyn, published in $15 \mathrm{I} 2$, entitled "Ballade de la Grosse Verole," in which the wealthy are warned of the dangers of the disease. At a period when some medical men held that it was spread through the air or by simple contact, it is surprising to find that Droyn regarded intercourse with harlots as the cause of its prevalence. Similar poems on " the Gorre" or "Grosse verole" were published in $\mathrm{I}_{525}$ by Jean Lemaire, who enumerated the numerous names the new disease had received in different countries, and by an anonymous writer in I539, entitled "La triomphe de tres haulte et puissant Dame Verolle," a poem in six cantos. Selections from each of the poems will be found in Jeanselme's " History of Syphilis." I will do no more than mention Fracastor's celebrated poem, "Syphilis sive Morbus Gallicus," first published in I530, from which the disease received its present name, as it is essentially a medical work. Of contemporary historians who allude to the new disease, Guicciardini (I485-I540) is undoubtedly the most famous. In his "Storia d'Italia" (Lib. II., c. 5 ad finem) he states that the calamity which arose from the passage of the French troops and spread all over Italy was either entirely new or unknown hitherto in our hemisphere. He also protested against the term of "French disease," because it was transported from Spain to Naples after having originated in the islands discovered by Columbus. It should be noted that the works of the early Spanish historians (collected by Monteio de Robledo) such as Oviedo (I478-I557), a distinguished Spanish courtier and scholar, and author of a Natural History of the Indies, Las Casas (I474-I566), bishop of Chiape and author of a General History of the Indies, and the Franciscan Father Bernardino de Sahagun (I499-I570), author of a History of New Spain, confirm the statements made by contemporary medical men as to the pre-Columbian existence 


\section{BRITISH JOURNAL OF VENEREAL DISEASES}

of syphilis among the American Indians (Bloch, Pusey, Williams, Rice and Lacayo).

Of the subsequent lay writers on syphilis in the sixteenth century, by far the most important is Erasmus (I466-I526), who, as Jeanselme points out, had gained a good knowledge of the disease from his unfortunate friend, the knight Ulrich von Hutten, who made an important contribution to the early medical literature of syphilis in a work in which he extolled the therapeutic value of guiacum from experience of it in his own attack. As will be seen from the following extracts, most of the allusions to the new disease in Erasmus's work will be found in his "Familiar Conversations." The close association between syphilis and prostitution which was not at first generally recognised is well illustrated in the colloquy between the young man and the harlot, in which the repentant young man addresses his former mistress in the following unkindly strain :-

"Thou makest thyself a common sewer, into which all the base, nasty, pocky Fellows resort, and empty their Filthiness, and if not leprous infection they call the French Pox hasn't yet seized thee, thou wilt not escape it long. And if once thou gettest it how miserable wilt thou be, though all things go favourably on thy Side, I mean thy Substance and Reputation. Thou wouldst be nothing but a living Carcase."

The prevalence of syphilis in the upper classes of society and its liability to infect other members of the patient's family are well set forth in the colloquy between the soldier and the Carthusian monk in which the latter exclaims :

"What spoils will you carry home to your Wife and Children? The Leprosy? for that Scab is only a Species of the Leprosy ; and it is only not accounted so, because it is the Disease in Fashion, and especially among Noblemen : and for this very Reason, it should be the more carefully avoided. And now you will infect with it those that ought to be dearest to you of any in the World, and you yourself will all your days carry about a rotten carcase."

The following extract from a letter (quoted by Jeanselme), though written by Erasmus in 1520, when the outbreak was beginning to abate, shows how deadly syphilis was at that time :- 


\section{VENEREAL DISEASE IN LITERATURE}

" If I were asked which is the most destructive of all diseases I should unhesitatingly reply, it is that which for some years has been raging with impunity.... What contagion has ever extended so quickly to all the countries of Europe, Asia and Africa? What contagion does thus invade the whole body, so much resist medical art, becomes inoculated so readily, and so cruelly tortures the patient? It combines in itself all the terrible features of other contagions, pain, infection, danger of death, disagreeable and repugnant treatment and one which does not produce a complete cure."

The manner of its acquirement, chronicity of the disease, severity of its course and inadequacy of treatment are also illustrated in the colloquy entitled " Epicurus":

"Hedonius: When young men by whoring, as it commonly falls out, get the Pox, which by way of Extenuation they call the Neapolitan itch, by which they are often brought to death's door in their Life-Time and carry about a dead Carcase do they not Epicurise gloriously?

"Spudaus: Yes, if coming often to the PowderingTub be doing so.

"Hedonius: When once a man has got the Pox he's. plagued with it all his Life-Time and forced to suffer a Sort of Death a great many Times over before the Time comes to die."

Perhaps the most interesting passage in Erasmus's writings dealing with syphilis is that contained in the colloquy entitled "The Unequal Marriage," which relates the marriage of Ulrich von Hutten under the name of Pompilius Blennus to a young and beautiful girl, although he was at that time suffering from a most hideous form of the disease. The colloquy contains advice regarding the use of separate beds, cups, linen and razors for the patients. As regards the behaviour of the luckless bride, it is recommended that she should clap her hands before her mouth whenever her husband offers to kiss her and should put on armour when she goes to bed with him.

Mention must next be made of the references to syphilis in the works of Rabelais, who was born twenty-eight years after Erasmus and outlived him six years. Everyone knows that Rabelais dedicated his work, not only to " most illustrious drinkers," but also to "precious and pockified blades." 


\section{BRITISH JOURNAL OF VENEREAL DISEASES}

The prevalence of syphilis in the sixteenth century may be gathered from the dialogue between Pantagruel and Epistemon, in which the latter relates that among the denizens of hell he had seen Pope Sixtus as an anointer of those that had the pox. "What," said Pantagruel, " have they the pox there too?" "Surely," said Epistemon, "I never saw so many as there are there, I think above a hundred millions. For be assur'd that those who have not had the pox in this world must have it in the next" (Lib. II., c. 30).

It is not improbable that Rabelais was having a sly hit at the numerous fanciful suggestions as to the origin of syphilis when he stated that Etion, one of the ancestors of Grangousier, Gargantua and Pantagruel, was the first to have the pox because he did not drink deep in summer (Lib., II., c. I).

According to Gillard, Rabelais recognised the nature of certain syphilitic manifestations such as hemiplegia, retraction of the tendons and laryngitis, as is seen in the passage in which he represents Pantagruel as imitating those who have the pox, for he twisted his face and retracted his fingers and called his companions in a husky voice.

As regards specific manifestations of the skin and bones, it is difficult not to recognise them in the description of certain lesions in some "scabby patients pocky to the bone," whom he lodges in the Sorbonne and drives away from the Abbaye de Thelème.

Marriage as a prophylactic method against syphilis is recommended in the following passage: "Were it not a great deal better for me," asks Panurge (III., ix.), " to apply and associate myself to some honest, lovely and virtuous woman than by a new change of females every day run a hazard of being bastinadoed (or what is worse) of the Great Pox, if not of both together?"

Lastly, the appearance of those who had undergone mercurial fumigations is described as follows (Prologue to Book II.) :-

"But what shall I say of those poor men that are plagued with the Pox and the Gout? O how often have we seen them, even immediately after they were anointed and thoroughly greased till their faces did glister like the Key-hole of a Powdering Tub, their Teeth dance like the Jacks of a Pair of Little Organs or Virginals when they I56 


\section{VENEREAL DISEASE IN LITERATURE}

are played upon and that they foamed from their very throats like a Boar which the Mongrel mastiff hounds have driven in and overthrown among the toils."

It is a remarkable fact to which Creighton has drawn attention that over eighty years elapsed before the great outbreak of syphilis at the end of the fifteenth century received notice in English medical literature, when William Clowes, surgeon to St. Bartholomew's Hospital, published his treatise on lues venerea in I576. Several $^{2}$ references, however, to the new disease appeared much earlier in the non-medical literature of Great Britain. According to Creighton, the earliest authentic allusions are to be found in the Council Register of the Borough of Aberdeen of April 2Ist, I497, which mentions "the infirmity cumm out of Franche," and in the minutes of the Town Council of Edinburgh for September 22nd, I497, where the disease is called the "Grangor."

The earliest reference in British belletristic literature to syphilis appears to be in the poem of William Dunbar (I465-I520) addressed to Queen Margaret, wife of James IV. of Scotland and sister of Henry VIII., in which the risk of contracting the disease from harlots is mentioned :-

I saw coclinkis (harlots) me besyd

The young men to their howses gyd, Had bettir liggit in the stockis ;

Sum fra the bordell wald nocht byd,

Quhill that thai get the Spanyie pockis.

Thairfor, all young men, I you pray,

Keip you fra harlottis night and day,

Thay sall repent quhai (who) with them yockis (embrace) ; And be war with that perellous play,

That men callis libbin (gelding) of the pockis.

In the "General Satire of Scotland," attributed, according to J. Y. Simpson, by most authorities to Dunbar and supposed to have been written in 1504, the writer deplores the extent to which the disease had spread in Scotland in the following words :-

Sic losing sarkis, so many Glangour markis

Within this land was never seen before.

Sir David Lindsay, another Scottish poet of the same period (I490-I557), alludes to the occurrence of syphilis in the royal jester at the Court of James IV., who 


\section{BRITISH JOURNAL OF VENEREAL DISEASES}

In his most triumphand gloir

For his reward got the Grangor.

Lindsay also includes the disease, along with gut (gout) and gravel, among the maladies :-

Quhilk humane nature dois abhor.

In I524, according to Creighton, or fifty-two years before the publication of the first edition of Clowes's treatise, Simon Fyshe, in his " Supplication of Beggars," said of certain priests: "These be they that corrupte the hole generation of mankynde in your realme, that catch the pockis of one woman and bear it to another, ye some one of them will boaste among his felowes that he hath medled with an hundredth wymen."

The Elizabethan Age.-The allusions to syphilis in Shakespeare, who calls it "the malady of France" (Henry V., V., i., 87), " the Neapolitan boneache" (Troilus and Cressida, II., iii., 235), and "the French crown" (All's Well that Ends Well, II., ii., 24), are discussed in Bucknill's monograph, Moyes's Glasgow M.D. thesis, St. Clair Thomson's address before the Medical Society of London, and Packard's more recent paper.

The prevalence and fatality of the disease are clearly shown in the clown's remark in the grave-digging scene in Hamlet (V., i.).

"We have many pocky corpses nowadays that will scarce hold the laying in."

The destructive nature of tertiary syphilitic lesions, affection of the larynx, alopecia and impotence are nowhere more strikingly depicted than in the following denunciation of Timon of Athens (IV., iii., I68-I8I) :-

Consumption sow

In hollow bones of man ; strike their sharp shins

And mar men's spurring. Crack the lawyer's voice

That he may never more false title plead,

Nor sound his quillets shrilly, hoar the flamen,

That scolds against the quality of flesh

And not believes himself; down with the nose,

Down with it flat; take the bridge quite away

Of him that his particular to foresee

Smells from the general weal, make curl'd pate ruffians bald

And let the unscarred braggarts of the war

Derive some pain from you ; plague all,

That your activity may defeat and quell

The source of all erection. 


\section{VENEREAL DISEASE IN LITERATURE}

The part played by harlots in the spread of the disease is illustrated by another bitter utterance of Timon addressing Alcibiades with reference to Phryne :-

This fell whore of thine

Hath in her more destruction than my sword

For all her cherubin look. (IV., 3.)

In Measure for Measure, II., ii., 5I-53, the powdering tub as one of the means of administering mercury is mentioned in the following passage where Lucio is speaking to the clown about a bawd :-

Lucio: Procures she still, ha?

Clown : Troth, sir, she has eaten up all the beef and she is herself in the tub.

(This passage is explained by Moyes as meaning that the same kind of tub was used as that for curing and corning meat.)

In George Chapman's play of All Fools, Act III., Sc. I, a surgeon named Pock is called to examine a wound, when the following conversation takes place :-

Pock : God save you, Signor Dariotto.

DARIOTTO: I know you not, sir, your name I pray.

Pock: My name is Pock, sir, a practitioner in surgery.

DAR.: Pock, the surgeon, you're welcome, sir. I know a doctor of your name, Master Pock.

Pock: My name has made many doctors, sir.

RINALDO: Indeed 'tis a worshipful name.

VALERIO: Marry is it and of an ancient descent.

Pock: Faith, sir, I could fetch my pedigree far if I were so disposed.

RIN.: Out of France at least.

In Beaumont and Fletcher's Knight of the Burning Pestle, Act III., Sc. 4, a man with a patch on his nose introduces himself as follows :-

I am a knight, Sir Pockhole is my name, and by my birth I am a Londoner. Free by my copy, but my ancestors were Frenchmen all.

In many other Elizabethan dramatists, such as Ben Jonson (I574-I637), Webster (I582-I652), Massinger (I584-I640) and Ford (I586-I639), the term "pox" is frequently used as an expletive, as it is in the dramatists of the Restoration, such as Killigrew (16r2-82), Wycherley (I640-1715), Congreve (I670-I704) and Dryden 


\section{BRITISH JOURNAL OF VENEREAL DISEASES}

(I650-I707), but comparatively few, and for the most part insignificant, allusions are made to venereal disease. Among the various causes put forward to account for the appearance of the new disease was that suggested, according to Buret, in $\mathrm{I}_{5} 64$ by Leonardo Fioravanti of cannibalism. This fantastic view, however, was maintained by no less a person than Lord Bacon, who in the "Sylva Sylvarum or Naturall History" (Cent. I., art. 26), published in I629, writes as follows :-

"The French (which put off the name of the French Disease into the name of the Disease of Naples) doe report that at the siege of Naples there were certain wicked merchants that Barrelled up Man's flesh (of some of that had beene lately slaine in Barbery) and sold it for Tunny: And that upon that foule and high nourishment, was the originall of the Disease. Which may well be. For that it is certaine that the Cannibals in the West Indies eat Man's flesh and the West Indies were full of the Pock when they were first discovered."

Eighteenth Century.-The prevalence and severity of syphilis throughout the eighteenth century receive mention in numerous non-medical works, such as the stories, history and philosophical writings of Voltaire, the "Mémoires" of Casanova, the novels of Defoe, Fielding and Smollett, the essays of Addison and Steele in the Spectator and Tatler, and the poems of Swift and Gay among others. Partly owing to the greater frequency of malignant cases and partly owing to inadequate treatment, syphilis was a much more fatal disease then than it is to-day. Casanova, for instance, mentions at least four deaths due to this cause. One example of the kind was Ancilla, a celebrated Venetian courtesan, who continued to be the mistress of Murray, the English Ambassador at Venice, although she was suffering from laryngitis and a destructive lesion of the face. Another victim of syphilis was Count Wagensberg, Governor of Trieste, who in Casanova's words " was seriously ill with a disease which is easily cured by mercury when it is skilfully administered, but fatal to the patient when he falls into unskilled hands, as did the poor count." Cases of mercurial intoxication during the treatment of venereal disease were not uncommon in the eighteenth century, and the celebrated Dr. Pangloss in Voltaire's "Candide" is a classical example of the kind.

Like Astruc, from whose treatise he had probably 


\section{VENEREAL DISEASE IN LITERATURE}

derived his knowledge of the disease, Voltaire based his belief in the American origin of syphilis, first on the evidence of a large number of physicians and surgeons of the sixteenth century, and secondly on the silence of all the medical writers and poets of antiquity (Dict. Phil., art. Lépre et vérole).

The distinction of leprosy from syphilis, the salivation, stomatitis and necrosis of the jaw so frequently associated with mercurial treatment in the eighteenth century, the illustrious victims of the disease, including royalty, nobility and high clergy, and the lucrative nature of a venereal practice all find mention, as I have shown elsewhere (I925), in various passages in Voltaire's works. Special mention, however, should be made of the passage in L'homme aux quarante écus, in which Voltaire makes the proposal which was not realised until I50 years later by the formation of the Union internationale contre le péril vénérien, that a league of nations should be formed for combating syphilis.

In my paper on the "Medical Interest of Casanova's "Mémoires " " (I9I7) I pointed out that Casanova, who was a typical example of a sexual athlete, had numerous attacks of venereal disease, one of which was probably syphilis. He appears to have sought medical advice on each occasion, and, like Benvenuto Cellini, who also relates his attack of venereal disease in his autobiography, he had no sequelæ, but retained his mental powers and general activity until his death at an advanced age.

As regards prophylaxis, numerous references are made in the "Mémoires" to condoms, which on one occasion induced Casanova to break out into two very indifferent pieces of verse on the subject. On all but two occasions, however, he appears to have used these safeguards for a contraceptive purpose and not as a prophylactic against venereal infection.

Reference may here be made to the bon mot attributed to Madame de Staël, who described the condom as a " cuirass against pleasure and a spider's web against danger."

$A$ propos of prophylaxis, I may allude to the scheme suggested by the encyclopædic writer, economist and novelist, Restif de la Bretonne, in his work " Le Pornographe," published in I769. It consisted in the establishment of state brothels in which not only were the women 


\section{BRITISH JOURNAL OF VENEREAL DISEASES}

to be inspected every morning, but also their male visitors, who were at once to be excluded if they were not found to be healthy (Picardeau). Drunkards were to be refused admission. A man who was proved to have contaminated a woman was treated in an infirmary attached to the Parthenion, as the brothel was called. Baths were to be provided every two days for the women, though it was only in the winter that they were to be warm. As Jeanselme remarks, Restif's well-known dissolute habits prevented his proposal from being taken seriously.

The best-known English novelists of the eighteenth century, viz., Defoe, Fielding and Smollett, make several allusions to syphilis. In view of Charles Lamb's remark ("Estimate of Defoe's Secondary Novels") that in no other book of fiction is the guilt and delinquency made less seductive, it is surprising to find that Moll Flanders, who, as the title of the story so named states, was for twelve years a whore, is allowed to escape an attack of the pox, especially as she indulges in the following reflections on those who contract the disease from fornication :-

"These are the men of whom Solomon says "they go like an ox to the slaughter, till a dart strikes through their liver'; an admirable description by the way of the foul disease, which is a poisonous, deadly contagion mingling with the blood whose centre or fountain is the liver; from whence by the swift circulation of the whole mass, that dreadful nauseous plague strikes immediately through his liver, and his spirits are infected, his vitals stabbed through as with a dart."

Roxana, another harlot heroine in Defoe's story of that name, enjoys similar immunity from the disease, although her trusty servant Amy, who kept a house of ill-fame, " had the French disease to a violent degree and died in hospital in a salivation."

In spite of his promiscuous amours, Tom Jones is as fortunate as Moll Flanders and Roxana in escaping infection, and indeed there is no mention of any venereal disease in the novel of "Tom Jones."

In "Amelia," on the other hand, we read of a Mrs. Bennet who was infected by a lord and in turn infected her husband, who died of "a polypus in the head"presumably cerebral syphilis. The lord subsequently "fell a martyr to his amours, by which at last he became 


\section{VENEREAL DISEASE IN LITERATURE}

so rotten that he stank above ground " ("Amelia," Bk. VII., cc. 8 and 9, and Bk. XII., c. 9).

It is in Smollett's novels, however, and in " Roderick Random " particularly, that we find most allusions to venereal disease, as was to be expected from the fact that Smollett was a qualified medical man. Examples of the unprincipled quacks who undertook to cure venereal disease by secret remedies are furnished by Mr. Lavement, the apothecary whom Roderick Random serves as an apprentice (Chapter XIX.), Ferdinand Count Fathom, in the novel of that name (Chapter LIV.), and another individual in "The Adventures of Humphrey Clinker."

Even University professors were not above reproach. In his " Travels through France and Italy," in a letter dated November I2th, I763, Smollett gives an account of "the celebrated Professor F- the Boerhaave of Montpellier," who had a great practice in venereal disease. "I have reason to think," says Smollett, "that Professor F- has, like the famous Mrs. Mapp, the bone setter, cured many patients that were never diseased."

From a copy of Smollett's "Travels in the British Museum Library" annotated by Smollett himself, it appears that Professor F- was Antoine Fize, a professor of medicine at Montpellier.

The close association between prostitution, syphilis, alcoholism and destitution is poignantly illustrated by the story of a certain Miss Williams, a character in "Roderick Random" (Chapters XXI. and XXIII.), who " in the course of her adventures found herself dangerously infected with a distemper to which all of her class are particularly subject. The most fashionable woman of the town is as liable to contagion as one in a much humbler sphere: she infects her admirers, her situation is public, her credit fails, her complexion fades, she grows nauseous to everybody, finds herself reduced to a starving condition, is tempted to pick pockets, is detected, committed to Newgate, where she remains in a miserable condition until she is discharged, because the plaintiff will not appear to prosecute her; the symptoms of the distemper are grown outrageous, she seeks to be admitted to a hospital, where she is cured at the expense of her nose. She is turned out naked into the streets, depends on the addresses of the lowest class, is fain to allay the 


\section{BRITISH JOURNAL OF VENEREAL DISEASES}

rage of hunger and cold with gin, degenerates into a brutal insensibility, rots and dies on a dunghill.'

Destruction of the nose as the result of wenching is repeatedly held out as a warning to his son by Lord Chesterfield (Letters 85, 87, I33, I64, I84 and I87), and a similar warning is given by Steele in the following paper in the Tatler, December 7 th, I7Io, after a description of the plastic work of Taliacotius, who is described as " the earliest clap doctor in history."

"I shall close this paper with an admonition to the young men of this town, which I think the more necessary because I see several fresh coloured faces that have made their first appearance in it this winter. I must therefore assure them that the art of making noses is entirely lost, and in the next place not to follow the example of our ordinary town rakes who live as if there was a Taliacotius to be met with at the corner of every street. . . . The general precept I shall leave with them is to regard every town woman as a particular kind of syren, that has a design upon their noses, and that amidst her flatteries and allurements, they will fancy she speaks to them in that humorous phrase of old Plautus. Ego tibi faciem denasabo mordicus, ' Keep your face out of my way or I will bite off your nose.'

Loss of the nose as the result of the pox is also mentioned in several of Swift's poems ("Pethox the Great," "Cassinus and Peter," the "Progress of Beauty," and "An Answer to a Scandalous Poem," and in his contemporary Gay ("Trivia," III., 285 et seq.).

Modern Times. - It is surprising to find that syphilis received comparatively little attention from the French realistic novelists of the second half of the nineteenth century. Martineau, for example, discovered only three vague references to the subject of venereal disease in the whole of Zola's works, and only a few scanty allusions are to be found in contemporary writers such as Maupassant, who in his "Lit No. 29" relates the story of the patriotic harlot who refused treatment so as to infect and kill as many Prussian soldiers as possible, or Huymans, who in his novel of " $\AA$ Rebours" describes the syphilitic nightmare of the neuropathic Les Esseintes. Moreover, in none of the French novels in which a harlot plays the principal part, such as "La Dame aux Camélias" of A. Dumas fils, Zola's "Nana," Daudet's "Sapho," 


\section{VENEREAL DISEASE IN LITERATURE}

Edmond de Goncourt's " La fille Elisa," or Huysmans' "Marthe," does the heroine contract any venereal disease.

The most remarkable feature of the belletristic literature of the nineteenth century connected with syphilis is that it contains for the first time descriptions of tabes and general paralysis. Professor Jeanselme has drawn attention to the fact that neither the medical nor the lay literature prior to Duchenne's classical paper on locomotor ataxy in 1858 has any description of the characteristic gait of the tabetic patient. In the nineteenth century at least three eminent literary men, namely, Heinrich Heine, the poet, Auguste Thierry, the historian, and Alphonse Daudet, the novelist, were victims of tabes, and two of them, Heine and Daudet, have left poignant descriptions of their sufferings.

In his characteristic jocosely blasphemous tone Heine relates in his "Confessions" the following history of his infection where he represents himself to be a new Messiah :-

"I was the living law of morality and the spring of all right and all authority. I was the primeval morality, I could commit no sin, I was purity incarnate, the most infamous Mary Magdalenes were purified by the refining and redeeming power of my flames of love, and spotless like lilies and blushing like chaste roses with an entirely new virginity they passed forth from the entrances of the god. These restorations of damaged maidens I confess sometimes exhausted my powers. But I gave without stint and inexhaustible was the spring of my compassion."

The description of the tortures endured by Daudet forms the subject of his posthumous work, "La Doulou," to which my attention was first drawn by the remarkable Paris thesis of Mme. Trivas.

Vivid pictures of tabes may be found in Rudyard Kipling's story of "Love-o'-Woman" (" Many Inventions ") and in Conan Doyle's "The Surgeon Talks" ("Round the Red Lamp").

The most remarkable description of general paresis in belletristic literature is to be found in Ibsen's " Ghosts " in the person of Oswald, in whom the development of the juvenile form of the disease is represented in a wonderfully realistic manner. A picture of the early stage of general paresis, as Even has shown, with its long pro- 


\section{BRITISH JOURNAL OF VENEREAL DISEASES}

dromal period and the essential symptoms of intellectual enfeeblement, is also given by Jules de Goncourt, himself a victim of the disease, and his brother Edouard in the novel "Charles Dumailly." As Voivenel and Lagriffe have shown in their brilliant little work, Maupassant wạs another victim of general paralysis, some of the symptoms of which he describes in his stories, particularly " La Horla " and " Lui."

The influence of Alfred Fournier at the beginning of this century on non-medical writers in the campaign against syphilis is shown by Brieux's dedication to him in Igor of his play "Les Avariés," subsequently adapted in this country under the title of "Damaged Goods," Michel Corday's novel "Vénus ou les deux risques" (I9OI), in which the risks of illicit intercourse are portrayed, and Victor Margueritte's "Prostituée" (I907), dealing with the inadequacy of State control of prostitution as a means of preventing venereal disease and the danger of treatment by quacks, and containing details of the skin, bone and nerve lesions of congenital and familial syphilis and extragenital infection.

\section{GONORRHEA}

According to Luys gonorrhœa is as old as the world. The first description in non-medical, and indeed in any literature, is that contained in Leviticus xv., commencing with the words "When any man hath a running issue out of his flesh, because of this issue he is unclean." The recognition at that early date of the contagious character of this issue is shown by the following verses, which emphasise the contamination of persons or objects by the sufferer and the necessity of purification by washing in running water. We have also the authority of Luys for the statements that very definite allusions to gonorrhœa are to be found in the works of the ancient philosophers such as Plato, Aristotle and Seneca, and that Epicurus himself suffered from the disease, although the evidence to my mind for such a charge seems to be very slight. Up to the middle of the sixteenth century, or nearly sixty years after the introduction of syphilis into Europe, syphilis and gonorrhœa were clearly separated from one another. In I $_{587}$, however, Brassavola made gonorrhœa merely one of the symptoms of syphilis, and this error was 


\section{VENEREAL DISEASE IN LITERATURE}

perpetuated until Bell, in I793, in England, and Bosquillon, in France, began to separate the two diseases, the separation being finally completed by Ricord in I83I (Luys). It was natural, therefore, that the idea of venereal disease being one and indivisible should long persist in lay literature. Rabelais, however, whose life occupied practically the first half of the sixteenth century, recognised the existence of chaude pisse as a distinct disease. In Lib. II., c. 33, he relates how " Pantagruel fell ill and was so afflicted in his stomach that he could neither eat nor drink, and because misfortunes never come singly he was tormented by a chaude pisse which tormented him more than you could imagine, but his doctors succoured him so well with many lenitive and diuretic drugs that they made him piss away his misfortune."

According to the Oxford Dictionary the earliest use of the word "clap," the origin of which is uncertain, was in 1587 , in a poem on King Malin in the "Mirour for Magistrates," in which the following lines occur :-

They give no heede before they get the clap

And then too late they wish they had been wise.

Owing to the confusion between syphilis and gonorrhœa, which lasted for about 250 years, the words " clap" and " pox" were used indiscriminately, as will be shown by the following quotations. In the first two passages the term "clap" is applied to the destructive tertiary lesions of syphilis.

(I) In a biographical note on Sir William Davenant, the Poet Laureate who succeeded Ben Jonson in I637, written at the end of the seventeenth century, though not published until I8I3, John Aubrey says: " He gott a terrible clap of a handsome wench that lay in Axe-Yard, Westminster, which cost him his nose, with which many wits were too cruelly bold.'

(2) In the issue of the Tatler of December 7 th, I7Io, which I have already quoted, Steele applies the designation "the earliest clap doctor in history" (changed in later editions to "love doctor") to Tagliacozzi, who did so much in the sixteenth century by his plastic operations to repair the ravages of syphilis on the nose.

On the other hand, in the following poem by Sir John Suckling (I607-I64I), entitled "Upon T(hornas) C(arew) 


\section{BRITISH JOURNAL OF VENEREAL DISEASES}

having the Pox," the ardor urinae of acute gonorrhœa, from which the author of "The Rapture" was suffering, is obviously indicated :-

\footnotetext{
Troth, Tom, I must confess I much admire

Thy water should find passage through the fire ;

For fire and water never could agree,

These now by nature have some sympathy,

Sure then his way he forces, for all know

The French ne'er grants a passage to his foe,

If it be so, his valour I must praise

That being weaker yet can force his ways ;

And with that to his valour he had strength

That he might drive the fire quite out at length

For, troth, as yet the fire gets the day

For evermore the water runs away.
}

The frequent association of gonorrhœa with syphilis as well as the discharge due to a urethral chancre doubtless explains the tendency of the old writers to regard clap as the early stage and syphilis the late stage of the pox. This view is incorporated in Pope's well-known line (" Satires of Dr. Donne," II., 47) :-

Time that at last matures a clap to pox.

In a paper communicated to the Royal Society in $17 \mathrm{I} 8$, entitled "An Attempt to prove the Antiquity of the Venereal Disease, long before the Discovery of the West Indies," a surgeon named William Beckett mentions a book written on vellum in the custody of the Bishop of Winchester, whose palace was situated on the Bankside near the stews, over which he had jurisdiction. This book, which is supposed to have been written about the year I430, contains an order that " No Stewholder keep noo woman wythin his Hous that hath any syckness of Brenning, but that she be pytte out upon the peyne of makeit a fyne unto the Lord of a hundred shylyngs.'

Beckett also alludes to a non-medical manuscript relating the story of a certain licentious Dr. Hugh Weston, Dean of Windsor in 1550, who "had been bitten by a Winchester Goose and was not healed therefore." The term "Winchester Goose," which is also found in Shakespeare (Troilus and Cressida, Act V., Sc. Io) and Webster (Cure for a Cuckold, Act IV., Sc. I), indicates one of the women of the stews under the jurisdiction of the Bishop of Winchester. 


\section{VENEREAL DISEASE IN LITERATURE}

All Beckett's cases obviously refer not to syphilis but to gonorrhœa, and his contention, which he repeats in a subsequent communication to the Royal Society in I720, that the "Burning" occurred some hundreds of years before the venereal disease became known in Europe, and that it was the first stage of the venereal disease, clearly illustrates the confusion that existed in his time between gonorrhœa and syphilis.

In Erasmus's colloquy of the Soldier and Carthusian, the following passage is strongly suggestive of spondylitis deformans of gonococcal origin in a syphilitic subject, if the eruption on the chin be regarded as an indication of syphilis :-

"Carth.: I see I can't tell what sort of rubies on your chin.

"Sold.: Oh, they are nothing.

"Carth.: I suspect that you have had the pox.

" Sold.: You guess very right, brother. It was the third time I had that distemper and it had like to have cost me my life.

" Carth.: But how came it that you walk so stooping, as if you were 90 years of age, or like a mower, or as if your back was broke?

"Sold.: The disease has contracted my nerves to that degree."

Among the numerous French poets of the Renaissance who alluded to venereal disease special mention may be made of Mathurin Regnier (I573-I6I3), who wrote two poems "Sur la chaude-pisse," from one of which the following extract may be quoted :-
Mon cas qui se lève et se hausse
Bave d'une étrange façon,
Belle, vous fournites la sauce
Lors que je fournis le poisson.
Las! si ce membre eut l'arrogance
De fouiller trop les lieux secrets
Qu'on lui pardonne son offense
Car il pleure assez ses péchés.

Claude D'Esternod (I590-I640) was also the author of a poem on the same subject.

In contrast with the numerous references to syphilis, there are only a few passages, to which Moyes and Alban Doran have drawn attention, in Shakespeare which allude even distantly to gonorrhœea under the name of 


\section{BRITISH JOURNAL OF VENEREAL DISEASES}

" burning" or the like, viz., in Comedy of Errors, IV., iii., 57, "light wenches will burn" ; Troilus and Cressida, V., ii., I94, " A burning devil take them" ; King Lear, III., ii., 84, " No heretic burn'd but wenches suitors" ; and II. Henry IV., II., iv., "She is in hell already and burns, poor soul!'"

In the few passages in which Voltaire alludes to gonorrhœa he usually employs the popular term chaude pisse. In one passage, however ("La Bible Enfin Expliquée, Nombres"), in which he uses the term gonorrhée, he makes a distinction between a non-contagious form, which we should call spermatorrhœa, and a virulent form, which he says was not known in France before the end of the fifteenth century, was well known to be contagious through sexual intercourse and if neglected was invariably followed by pox.

In the "Mémoires" of Casanova we read of several persons who contracted an illness which was probably gonorrhœa. Casanova himself had at least four attacks of this disease as well as five of chancroid and possibly one of syphilis (von Notthaft). On two occasions he was treated by mercury, which in the eighteenth century was used indiscriminately for gonorrhœa, syphilis and soft chancre. His second attack gave rise to an epidemic in which more than fifty persons were infected and thereby made the fortune of the practitioner at Orsera, whom Casanova met unexpectedly the following year. "For twenty years," said the doctor, "I practised in the town where I lived in poverty, for I had only a few bleedings and cuppings to perform, and scratches and sprains to cure. My earnings were not enough to support me. But ever since last year I can say that my condition has changed. I have made much money and invested it profitably."

The disablement affecting his servant, whose attack was particularly severe, suggests polyarthritis or polyneuritis. The young officer who confessed to Casanova that after ten attacks he had become tired of following treatment, and for the last two years had become resigned to his fate, was obviously suffering from gleet.

It was doubtless an attack of gonorrhœea, " the sykness of Brenning " of the fifteenth century, that Fielding had in mind when in speaking of the amorous chambermaid Betty who tried to seduce Joseph Andrews he relates 


\section{VENEREAL DISEASE IN LITERATURE}

that " an ensign was the first person who made an impression upon her heart : he did, indeed, raise a flame in her which required the care of a surgeon to cure" (" Joseph Andrews," Bk. I., c. I8). Another probable allusion in the same novel to an attack of gonorrhœa is to be found in the case of a Mr. Wilson. This man relates how his fast life was put a stop to by his surgeon, who convinced him of the necessity of confining himself to his rooms for a month. " "I think," " said Parson Adams, " the advice of a month's retirement and reflection was very proper. I should rather have expected it from a Divine than a Surgeon.' The gentleman smiled at Adams's simplicity without explaining himself further on such an odious subject."

\section{Chancroid}

The history of chancroid is probably as old as that of gonorrhœea, and it would not be too daring to suggest that some of the penile lesions described by the Roman poets were of this nature. The first undoubted description, however, of soft chancre in non-medical literature is that quoted by Jeanselme (I920) from Palladius, an historian of the fourth century A.D. The passage relates to a certain monk who developed an ulcer on the glans after coitus with an actress whom he had met in Alexandria. He was ill for six months and his external genitals dropped off, but finally he recovered.

Girtanner alludes to several cases of destructive and fatal lesions of the penis reported by lay writers such as Josephus, Pliny the younger, and Eusebius, which were probably of the nature of phagedænic chancroid.

Iwan Bloch has pointed out that gangrenous lesions of the genitals, which appear to have been as prevalent in the Middle Ages as they were in classical antiquity, were not described by the earliest syphilographers as manifestations of the new disease, but were regarded as quite distinct from it.

According to a MS. in Lincoln College, Oxford, mentioned by Beckett (I720), the writer, Thomas Gascoigne, the celebrated Chancellor of Oxford University and a doctor of theology, had known several men die of putrefaction of their genitals caused by carnal copulation with women. Two of these are mentioned by name, one being the illustrious John of Gaunt, who is described as a 


\section{BRITISH JOURNAL OF VENEREAL DISEASES}

great soldier and a great fornicator, and the other an obscure bachelor of theology named Willus. Such cases can best be interpreted as examples of phagedænic gangrene.

Owing to the identification of syphilis and chancroid which took place in the medical world within sixty years of the appearance of the former in Europe, it cannot be supposed that any distinct description of chancroid would appear in non-medical literature from the end of the sixteenth century until modern times.

Chancroid, however, may be meant as well as gonorrhoa in the following imprecation in Rochester's poem entitled "The Imperfect Engagement" addressed to his impotent member :-

\section{Mayst thou to rav'nous Shankers be a prey \\ Or in consuming weepings waste away.}

Apart from Casanova's five attacks of venereal disease, which were interpreted by von Notthaft on somewhat slender evidence as soft chancre, the only other passage suggesting that condition in non-medical literature that I know is the following extract from Rabelais (Lib. I., c. 38) :-

"Gargantua caught one of the pilgrims by the codpiece, which snatch nevertheless did him a great deal of good, for it broke upon him a pocky botch he had in the groin which previously tormented him."

\section{SUMMARY}

(I) The value of the allusions made by lay writers in various ages to venereal disease is indicated by the attention given them by numerous medical historians.

(2) In spite of the statements to the contrary, there is no definite evidence in non-medical literature that syphilis existed in biblical times, classical antiquity or the Middle Ages.

(3) In the sixteenth century the best-known lay writers who refer to syphilis are Guicciardini, the historian, Erasmus and Rabelais.

(4) In the seventeenth century numerous references to syphilis are to be found in Shakespeare and other Elizabethan dramatists.

(5) In the eighteenth century the prevalence and I72 


\section{VENEREAL DISEASE IN LITERATURE}

severity of syphilis are illustrated in the works of Voltaire, Casanova, Defoe, Fielding, Smollett, Addison, Steele, Swift, Gay and Chesterfield.

(6) The belletristic literature of the nineteenth century contains for the first time descriptions of tabes and general paralysis (Heine, Daudet, Jules de Goncourt, Conan Doyle and Kipling).

(7) The antisyphilitic campaign of the drama and novel in France at the beginning of the twentieth century was inspired by Alfred Fournier.

(8) Gonorrhœa, of which the first description is in Leviticus, dates from remote antiquity. Owing to its identification with syphilis for about 250 years, the terms "clap" and " pox" in non-medical literature are used indiscriminately, the former being sometimes applied to tertiary syphilis and the latter to acute gonorrhœa.

(9) Chancroid is probably as old as gonorrhœe and was well known in classical antiquity and the Middle Ages.

\section{REFERENCES}

Astruc, J. : “A Treatise of the Venereal Disease." Translated by William Barrowby, M.B., I737.

Becketr, W. : Phil. Trans., I7I9, XXX., 839; I720, XXXI., 47.

BLOCH, I. : “ Ursprung der Syphilis," IgII ; "System of Syphilis " (D'Arcy Power and Murphy, J. K.), 2nd edition, I9I4, I., 3.

BuCknill, J. C. : “The Medical Knowledge of Shakespeare," r86o. BURET, F.: " Syphilis in Ancient and Prehistoric Times," translated by A. H. Ohmann-Dumesnil, I89I ; " Le Gros mal du moyen-âge et la syphilis actuelle," I894.

CReighton, C. : "History of Epidemics in Britain," I894, I., 4I7.

Doran, A. : " Shakespeare's England," I9I6, I., 439.

Dufour, P. : “ Histoire de la Prostitution," r85I.

EBSTEIN, W. : “Die Medizin im alten Testament,” Igor, 88.

ERASmus : "Colloquies," translated by N. Bailey, rgro.

Even, P. Y. : Thèses de Paris, I9I7-I8, No. 258.

FREIND, J. : "The History of Physick," I727.

Gillard, C. F. : Thèses de Paris, I9I9-20, No. 305.

GIRTANNER, C.: "Abhandlung über die venerische Krankheit," I793.

Hensler, P. G. : “ Geschichte der Lustseuche,” I783.

Hirsch, A. : "Handbook of Historical and Geographical Pathology," translated by C. Creighton, New Syd. Soc., I894, II., 59 et seq.

JeAnselme, E. : "Histoire de la syphilis" in "Traité de la Syphilis" (Jeanselme), I93I ; Bull. Soc. franç. hist. de méd., I920, XIV., 233.

LE ClERC, D. : “ Histoire de la Médecine," I723, 789.

Le Pileur, L. : Jour. de méd. de Paris, I920, XXII., 4 I5.

Leveque, P. R. : Thèse de Paris, I925, No. 258.

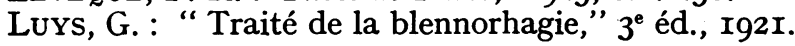




\section{BRITISH JOURNAL OF VENEREAL DISEASES}

Martineau, H. Thèses de Paris, I906-7, No. 23 I.

Moore, N. : Proc. Roy. Soc. Med., I9I2, V., Discussion on Syphilis.

Moyes, J.: "Medicine and Kindred Arts in the Plays of Shakespeare," I896.

NotThaft, von A. : Dermat. Woch., I9I3, LVII., I359.

Packard, F. R. : Ann. Med. Hist., I924, VI., I94.

Picardeau, R. F.: Thèse de Paris, I929, No. I53.

PREUSS: Quoted by Jeanselme, I93I, 27.

PRocksch, J. K. : "Die Geschichte der venerischen Krankheiten," 1895 .

Pusey, W. A. : "The History and Epidemiology of Syphilis," I933.

RABELAIS, F.: Translated from the French and illustrated by explanatory notes by M. Le Du Chat and others in four volumes, I784. Rivas, N. : These de Paris, 1932, No. 418.

Rolleston, J. D. : Proc. Roy. Soc. Med., I9I3-I4, VII., sect. Hist. Med., 3, 30 ; ibid., I9r5-I6, VIII., sect. Hist. Med., 49, 72 ; Janus, I9I7, XXII., II5 ; Urol. \& Cut. Rev., I9I7, XXI., 260 ; Proc. Roy. Soc. Med., I925-26, XIX., sect. Hist. Med., I7, 79; Brit. Jour. Derm. and Syph., I933, LXV., 62.

Rosenbaum, J. : "Die Lustseuche in Alterthume," 1839.

Simpson, J. Y.: Trans. Epid. Soc., I860, I., I44.

SudHoff, K., and Singer, C.: "The Earliest Printed Literature on Syphilis," I925.

Thomson, St. Clair : Trans. Med. Soc. Lond., I9I6, XXX1X., 257, I773; XVIII., 74 .

TRIVAS, M.: Thèse de Paris, I932, No. 4I8.

VAN SwIETEN, G.: "The Commentaries upon the Aphorisms of Hermann Boerhaave," I 744 .

Voivenel, P., et LAGriffe, L. : "Sous la signe de la P.G. La folie de Maupassant," I929.

Williams, H. U., Rice, J. P., and Lacayo, J. R. : Arch. Derm. and Syph., I927, XVI., 683 .

The following books as illustrative of his address were exhibited by Dr. Rolleston :-

Historical works of Astruc, Girtanner, Hensler, Jeanselme, Pusey, Rosenbaum, and Sudhoff and Singer. Familiar conversations of Erasmus (English and Latin versions). Fracastor's Poems. Gay's "Trivia " and Swift's " Pethox the Great." Brieux's "Les Avariés." Alphonse Daudet's "La Doulou." Maupassant's story "Le Lit 29." Conan Doyle's story "The Surgeon Talks." Papers on "Voltaire and Medicine." "The Medical Interest of Casanova's 'Mémoires," and "Sexology and Venereal Diseases in Casanova's 'Mémoires.'"

In addition to the above, Sir D'Arcy Power kindly lent: (I) A copy of the I557 edition of the "Epistolæ Obscurorum Virorum," which the original owner had rebound as a prayer-book with gilded edges. (2) A copy of "A Brief and Necessary Treatise on the Cure of the Disease called Morbus Gallicus or Lues Venerea," by William Clowes, London, I585. (3) Urquhart and Motteux's translation of the works of Francis Rabelais, M.D., in two volumes, London, I708 ; "The Life of Benvenuto Cellini," in two volumes. (5) "Many Inventions," by Rudyard Kipling, containing "Love-o'-Women," a study of locomotor ataxy, London, 1893 . 